States v. Vertellus Agriculture \& Nutrition Specialties $L L C$, Civil Action No. 1:09-Cv-1030-SEB-TAB (S.D. Ind.) was lodged with the United States District Court for the Southern District of Indiana. The Consent Decree addresses alleged violations of the Clean Air Act, 42 U.S.C. 7401-7671q, and its implementing regulations at a specialty chemical manufacturing facility in Indianapolis, Indiana that is owned and operated by Vertellus Agriculture \& Nutrition Specialties LLC ("Vertellus"). The United States alleges that Vertellus has failed to comply with certain requirements governing the control of hazardous air pollutant emissions under Clean Air Act Section 112, 42 U.S.C. 7412, and the implementing regulations at: (i) 40 CFR Part 63, Subpart H (National Emission Standards for Organic Hazardous Air Pollutants for Equipment Leaks); (ii) EPA Reference Method 21 at 40 CFR Part 60, Appendix A; and (iii) 40 CFR Part 63, Subpart GGG (National Emission Standards for Hazardous Air Pollutants for Pharmaceuticals Production). The United States also alleges a violation of Clean Air Act Section 502(a), 42 U.S.C. 7661a(a), for failure to comply with a requirement of Vertellus' permit issued under Title $\mathrm{V}$ of the Act.

The proposed Consent Decree would resolve the claims alleged in the United States' Complaint in exchange for the Defendant's commitment to implement appropriate injunctive relief, pay $\$ 450,000$ civil penalty, and perform a \$705,000 Supplemental Environmental Project. Among other things, the injunctive relief provisions of the Decree would require Vertellus to implement an enhanced leak detection and repair program and a program to operate and maintain an incinerator in a manner consistent with good air pollution control practices for minimizing emissions.

The Department of Justice will receive comments relating to the Consent Decree for a period of thirty (30) days from the date of this publication. Comments should be addressed to the Assistant Attorney General, Environment and Natural Resources Division, and mailed either electronically to pubcommentees.enrd@usdoj.gov or in hard copy to P.O. Box 7611, U.S. Department of Justice, Washington, DC 20044-7611. Comments should refer to United States v. Vertellus Agriculture \& Nutrition Specialties LLC, Civil Action No. 1:09CV-1030-SEB-TAB (S.D. Ind.) and D.J. Ref. No. 90-5-2-1-09022.

The Consent Decree may be examined at: (1) The offices of the United States Attorney, 10 West Market Street, Suite
2100, Indianapolis, Indiana; and (2) the offices of the U.S. Environmental Protection Agency, Region 5, 77 West Jackson Boulevard, 14th Floor, Chicago, Illinois. During the public comment period, the Consent Decree may also be examined on the following Department of Justice Web site: http://

www.usdoj.gov/enrd/

Consent Decrees.html. A copy of the Consent Decree may also be obtained by mail from the Department of Justice

Consent Decree Library, P.O. Box 7611, Washington, DC 20044-7611 or by faxing or e-mailing a request to Tonia Fleetwood (tonia.fleetwood@usdoj.gov), fax no. (202) 514-0097, phone confirmation number (202) 514-1547. In requesting a copy from the Consent Decree Library, please enclose a check in the amount of $\$ 15.75$ (63 pages at 25 cents per page reproduction cost) payable to the U.S. Treasury.

Maureen M. Katz,

Assistant Chief, Environmental Enforcement Section, Environment and Natural Resources Division.

[FR Doc. E9-20602 Filed 8-26-09; 8:45 am] BILLING CODE 4410-15-P

\section{DEPARTMENT OF JUSTICE}

\section{Notice of Lodging of Consent Decree Under the Clean Water Act}

Notice is hereby given that on August 24, 2009, a proposed Consent Decree in United States v. Ameripride Services, Inc., Civil Action No. 3:09-Cv-1333 (WWE), was lodged with the United States District Court for the District of Connecticut.

In this action, the United States seeks, inter alia, civil penalties and injunctive relief from Ameripride for alleged violations under the Clean Water Act, 33 U.S.C. $\S \S 1319(\mathrm{~b})$ and (d), at its Hartford, Connecticut laundry facility. The complaint in this matter alleges that Ameripride violated Federal

pretreatment standards and State permit limitations in relation to discharges from the facility which contained excess $\mathrm{pH}$, oil/grease and metals. The Consent Decree requires Ameripride, among other things, to pay a civil penalty of $\$ 525,000$ and submit periodic reports relating to its future compliance with the Act.

The Department of Justice will receive for a period of thirty (30) days from the date of this publication comments relating to the Consent Decree. Comments should be addressed to the Assistant Attorney General,

Environment and Natural Resources Division, and either e-mailed to pubcomment-ees.enrd@usdoj.gov or mailed to P.O. Box 7611, U.S. Department of Justice, Washington, DC 20044-7611, and should refer to United States v. Ameripride Services, Inc., D.J. Ref. 90-5-1-1-09559.

The Consent Decree may be examined at the Office of the United States Attorney, District of Connecticut, Connecticut Financial Center, 157 Church Street, Floor 23, New Haven, Connecticut 06510. During the public comment period, the Consent Decree may also be examined on the following Department of Justice Web site, to http://www.usdoj.gov/enrd/ Consent_Decrees.html. A copy of the Consent Decree may also be obtained by mail from the Consent Decree Library, P.O. Box 7611, U.S. Department of Justice, Washington, DC 20044-7611 or by faxing or e-mailing a request to Tonia Fleetwood (tonia.fleetwood@usdoj.gov), fax no. (202) 514-0097, phone confirmation number (202) 514-1547. In requesting a copy from the Consent Decree Library, please enclose a check in the amount of $\$ 7.50$ (25 cents per page reproduction costs of Consent Decree and Appendices) payable to the U.S. Treasury or, if by e-mail or fax, forward a check in that amount to the Consent Decree Library at the stated address.

\section{Maureen Katz,}

Assistant Chief, Environmental Enforcement Section, Environment and Natural Resources Division.

[FR Doc. E9-20715 Filed 8-26-09; 8:45 am] BILLING CODE 4410-15-P

\section{DEPARTMENT OF AGRICULTURE}

\section{DEPARTMENT OF JUSTICE}

\section{Antitrust Division}

\section{Agriculture and Antitrust Enforcement Issues in Our 21st Century Economy}

AGENCIES: U.S. Department of Agriculture and U.S. Department of Justice, Antitrust Division.

ACTION: Notice of public hearings and opportunity for comment.

SUMMARY: The Antitrust Division of the U.S. Department of Justice (DOJ) and the United States Department of Agriculture (USDA) strongly believe that a

competitive agriculture sector is vitally important to producers and consumers alike. To this end, the DOJ and USDA, with the participation of State Attorneys General, intend to hold a series of public workshops to explore competition issues affecting the agricultural sector in the 21st Century and the appropriate role for antitrust 
and regulatory enforcement in that sector. Agricultural producers and their representatives have expressed concerns about changes in the agricultural marketplace, including increasing processor concentration in some commodities. There have been several congressional oversight hearings related to competition in the agricultural sector, as well as legislative proposals to restrict the activities of agricultural processors and intensify federal government scrutiny of agricultural mergers.

The workshops will address the dynamics of competition in agriculture markets, including, among other issues, buyer power (also known as monopsony) and vertical integration. They will examine legal doctrines and jurisprudence and current economic learning, and will provide an opportunity for farmers, ranchers, consumer groups, processors, agribusinesses, and other interested parties to provide examples of potentially anticompetitive conduct and to discuss any concerns about the application of the antitrust laws to the agricultural sector. The goals of the workshops are to promote dialogue among interested parties and foster learning with respect to the appropriate legal and economic analyses of these issues as well as to listen to and learn from parties with real-world experience in the agricultural sector.

To begin, the DOJ and USDA are soliciting public comments from lawyers, economists, agribusinesses, consumer groups, academics, agricultural producers, agricultural cooperatives, and other interested parties. The DOJ and USDA are interested in comments on the application of the antitrust laws to monopsony and vertical integration in the agricultural sector, including the scope, functionality, and limits of current or potential rules. The DOJ and USDA are also inviting input on additional topics that might be discussed at the workshops, including the impact of agriculture concentration on food costs, the effect of agricultural regulatory statutes or other applicable laws and programs on competition, issues relating to patent and intellectual property affecting agricultural marketing or production, and market practices such as price spreads, forward contracts, packer ownership of livestock before slaughter, market transparency, and increasing retailer concentration.

The DOJ and USDA plan to hold the first workshop in early 2010. While some of these workshops may be held in Washington, DC, others will be held regionally. The DOJ and USDA plan to publish a more detailed description of the topics to be discussed before each workshop and to solicit additional submissions about each topic. The workshops will be transcribed and placed on the public record. Any written comments received also will be placed on the public record.

DATES: Any interested person may submit written comments responsive to any of the topics addressed in this Federal Register notice. Respondents are encouraged to provide comments as soon as possible, but no later than

December 31, 2009.

ADDRESSES: Written comments should be submitted in both paper and electronic form to the Department of Justice. All comments received will be publicly posted. The comments should be submitted as follows:

Two paper copies should be addressed to the Legal Policy Section, Antitrust Division, U.S. Department of Justice, 450 5th Street, NW., Suite 11700, Washington, DC 20001. The Antitrust Division is requesting that the paper copies of each comment be sent by courier or overnight service, if possible, because U.S. postal mail at the Department is subject to delay due to heightened security precautions. The electronic version of each comment should be submitted by electronic mail to agriculturalworkshops@usdoj.gov. FOR FURTHER INFORMATION CONTACT: Mark B. Tobey, Special Counsel for State Relations and Agriculture, Antitrust Division, U.S. Department of Justice, 950 Pennsylvania Ave., NW., Washington, DC 20530; telephone: (202) 532-4763; e-mail: agriculturalworkshops@usdoj.gov. Detailed agendas and schedules for the workshops will be made available on the Antitrust Division's Web site, http://www.usdoj.gov/atr.

\section{SUPPLEMENTARY INFORMATION: The}

Horizontal Merger Guidelines recognize monopsony power and its exercise as a concern in analyzing potential competitive effects of proposed mergers and acquisitions. As a general proposition, the analysis of competitive issues in monopsony cases is the mirror image of the more common analysis of competitive issues in monopoly cases.

For example, instead of determining whether the merged firm would gain sufficient market power to raise prices to consumers, monopsony analysis focuses on whether the merged firm would gain sufficient market power to depress prices paid to its suppliers. Likewise, instead of determining whether the buyers could defeat an attempt by the merged firm to increase prices by a small but significant and non-transitory amount by switching to alternative products or alternative suppliers, the issue in a monopsony investigation is whether the sellers could defeat an attempt by the merged firm to depress prices by producing other products or by selling their products to other buyers.

Vertical integration occurs when multiple stages of production, for example, processing, distribution, or marketing, are brought together in one firm or are linked by contracts. In many instances, vertical integration may be procompetitive, allowing firms to reduce their costs. However, there may be circumstances in which vertical integration raises antitrust concerns, usually by increasing barriers to entry, facilitating collusion, or circumventing regulation.

Christine A. Varney,

Assistant Attorney General, Antitrust Division.

Ann Wright,

Deputy Undersecretary for Marketing and Regulatory Programs, Department of Agriculture.

[FR Doc. E9-20671 Filed 8-26-09; 8:45 am] BILLING CODE P

\section{NUCLEAR REGULATORY COMMISSION}

[NRC-2009-0376; Docket No.: 07007001; Certificate No. GDP-1; EA-08-280]

\section{In the Matter of United States Enrichment Corporation, Paducah Gaseous Enrichment Plant; Confirmatory Order (Effective Immediately)}

I

The United States Enrichment Corporation (USEC), a subsidiary of USEC Inc., is the holder of NRC Certificates of Compliance (COC) No. GDP-1 issued by the NRC pursuant to 10 CFR part 76 on November 26, 1996, and renewed on December 22, 2008. The COC is set to expire on December 31,2013 . The certificate authorizes USEC to operate the Paducah Gaseous Diffusion Plant (Paducah), located near Paducah, Kentucky. The certificate also authorizes USEC to receive, and other NRC licensees to transfer to USEC, byproduct material, source material, or special nuclear material to the extent permitted under the COC.

This Confirmatory Order is the result of an agreement reached during an alternative dispute resolution (ADR) mediation session conducted on July 1, 2009. 